\title{
Effect of dehydrated lucerne on lamb performance and protein and energy deposition in the body
}

\author{
M. Urbaniak \\ Department of Animal Nutrition and Feed Management, \\ Agricultural University of Poznań \\ Wotynska 33, 60-637 Poznań, Poland
}

(Received 2 September 1994; accepted 14 September 1994)

\begin{abstract}
Forty Polish Merino lambs weighing about $17 \mathrm{~kg}$ were divided into five groups and fed five isonitrogenous and isoenergetic diets containing $0,5,10.15$, and $20 \%$ dehydrated lucerne (DL). The animals were fattened to a final live weight of about $36 \mathrm{~kg}$. As the DL concentration in diets increased from 0 to $10 \%$, a significant $(\mathrm{P} \leqslant 0.05)$ parallel rise of mean daily live weight gains from 173 to $191 \mathrm{~g} / \mathrm{d}$ was observed, followed by a decrease of gains when the DL content increased to 15 and $20 \%$. Lambs fed the $10 \%$ DL diet used the smallest amount of protein and energy for at unit of gain. The level of DL in the diet did not have a significant effect on the chemical composition and energetic value of $1 \mathrm{~kg}$ empty body weight ( $\mathrm{EBW}$ ). The highest value of the utilization coefficient of metabolizable cnergy available for growth $\left(\mathrm{k}_{\mathrm{f}}\right)$ was found in lambs fed diets with $10 \% \mathrm{DL}(0.33)$, and the lowest in animals from the control group $(0.27)$. Lambs fed $10 \%$ DL deposited significantly $(P \leqslant 0.05)$ more protein in EBW $(29.52 \mathrm{~g} / \mathrm{d})$, in wool gain $(3.90 \mathrm{~g} / \mathrm{d})$ and in total gain $(33.42 \mathrm{~g} / \mathrm{d})$ than animals from the control group.
\end{abstract}

KEY WORDS: dehydrated luccrne, lambs, protein, energy deposition

\section{INTRODUCTION}

Intensive fattening of lambs requires the use of high levels of concentrates in diets as well as protein which must escape rumen degradation and be available for absorption in the small intestine (Loerch et al., 1983; Linda and Wohlt, 1985). Feeding high-concentrate or all-concentrate, low fibre, pelleted diets decreases salivary production and rumen $\mathrm{pH}$, alters microbial fermentation and, therefore, dietary buffers are necessary as agents preventing acidic conditions (Linda and Wohlt, 1985; Stroud et al., 1985). 
Ha et al. (1983), Stroud et al. (1985) and Urbaniak and Przybecki (1994) indicate that dehydrated lucerne (DL) can be used in diets for growing ruminants both as a buffering agent and a protein source with a limited level of ruminal degradation which increases the $\mathrm{pH}$ of the rumen liquid, the acetic to propionic acid ratio and the amino acid flow through the duodendum. DL is a feed rich in lysine, calcium, phosphorus and crude fibre and also has been used to replace concentrate in rations for lactating dairy cows (Christensen and Cochran, 1983; Kirkpatrick et al., 1984; Price et al., 1988).

However, few experiments were conducted concerning the effect of DL on lamb performance, body composition and protein and energy deposition in empty body weight.

The aim of this study was to determine the influence of different levels of DL in all-concentrate, pelleted diets on live weight gains, wool production and fecd utilization as well as on the chemical composition of empty body weight (EBW) and protein and energy deposition in lamb body using the comparative slaughter technique.

\section{MATERIAL AND METHODS}

Forty rams of the Polish Merino breed weighing $17 \mathrm{~kg}$ were randomly allocated to five groups ( 8 animals in each) and fed five isonitrogenous (approximately $16 \%$ crude protein $/ \mathrm{kg}$ dry matter) and isoenergetic (approximately $12.8 \mathrm{MJ}$ metabolizable energy $/ \mathrm{kg}$ dry matter) all-concentrate, pelleted diets containing $0,5,10,15$, and $20 \%$ of DI. The DL used in the experiment contained $19.1 \%$ crudc protein, $37.8 \%$ neutral detergent fibre (NDF) and $30.6 \%$ acid detergent fibre (ADF). The lucerne was dried in a dehydrator drum with an exhaust temperature of $135^{\prime \prime} \mathrm{C}$. The extent of rumen degradation of DL protein was estimated earlier by Urbaniak and Przybecki (1994) using the nylon bag technique. They found that after $24 \mathrm{~h}$ incubation, $61.2 \%$ crude protein of DL escaped rumen degradation. The components of the diets are listed in Table 1, while their chemical composition and energetic value are given in Table 2 . The dietary metabolizable energy (ME) contents were calculated on the basis of our own results of chemical analysis using equation $\mathrm{N}^{\text {" }} 75$ given by MAFF (1975):

$\mathrm{MJ} \mathrm{ME} / \mathrm{kg} \mathrm{DM}=0.012 \mathrm{x}_{1}+0.031 \mathrm{x}_{2}+0.005 \mathrm{x}_{3}+0.014 \mathrm{x}_{4}$

in which $\mathrm{x}_{1}, \mathrm{x}_{2}, \mathrm{x}_{3}$ and $\mathrm{x}_{4}$ designate dielary content ( $\mathrm{g} / \mathrm{kg}$ dry matter) of crude protein, ether extract, crude fibre and $\mathrm{N}$-free extractives, respectively.

Before the beginning of the experiment 4 additional lambs weighing $17 \mathrm{~kg}$ were selected, sheared and slaughtered to determine the amount of fleece and chemical composition of their body (zero group). The experimental animals were penned individually and fed one of five rations in the amount of $900 \mathrm{~g} / \mathrm{head}^{-1} / \mathrm{d}^{-1}$ (live weight of animals $17.5-25.0 \mathrm{~kg}$ ) and later $1300 \mathrm{~g} / \mathrm{head}^{-1} / \mathrm{d}^{-1}$ (live weight of 
TABLE 1

Composition of complete pelleted diets, $\%$

\begin{tabular}{|c|c|c|c|c|c|}
\hline \multirow{2}{*}{ Ingredicnt } & \multicolumn{5}{|c|}{ Dehydrated lucerne, $\%$} \\
\hline & 0 & 5 & 10 & 15 & 20 \\
\hline Dehydrated lucerne & 0.0 & 5.0 & 10.0 & 15.0 & 20.0 \\
\hline Rapeseed meal & 5.3 & 4.5 & 4.2 & 4.5 & 4.1 \\
\hline Ground barley & 20.4 & 25.5 & 23.0 & 25.5 & 31.2 \\
\hline Wheat bran & 30.0 & 30,0 & 27.8 & 20.0 & 18.0 \\
\hline Ground triticale & 10.0 & 10.0 & 10.0 & 10.0 & 10.0 \\
\hline Ground oats & 32.4 & 23.2 & 23.4 & 23.6 & 15.5 \\
\hline Limestone & 1.5 & 1.4 & 1.2 & 1.0 & 0.8 \\
\hline Trace mineral salt ${ }^{3}$ & 0.3 & 0.3 & 0.3 & 0.3 & 0.3 \\
\hline Vitamin mixture & 0.1 & 0.1 & 0.1 & 0.1 & 0.1 \\
\hline
\end{tabular}

a contains: $\mathrm{NaCl}-95.8 \% ; \mathrm{Zn}-0.30 \% ; \mathrm{Mn}-0.38 \% ; \mathrm{Fe}-0.18 \% ; \mathrm{J}-0.008 \% ; \mathrm{Co}-0.08 \%$

${ }^{b}$ contains: 2000000 IU vilamin $\mathrm{A} / \mathrm{kg}$ and $200000 \mathrm{IU}$ vitamin $\mathrm{D} / \mathrm{kg}$

animals $25.1-35.8 \mathrm{~kg}$ ). Their rations were split into equal parts which were fed at 07.00 and $14.00 \mathrm{~h}$. During fattening live weight and feed intake were recorded. The trial was terminated when the lambs reached a weight of about $36 \mathrm{~kg}$. Then they were sheared, starved for $20 \mathrm{~h}$ and slaughtered. Fleece yield was determined by shearing and samples of fleece from the shoulder, flank and thigh were collected to determine the yield of clean wool. Animals from the zero group were treated similarly. The EBW of lambs was expressed as the sum of all slaughter products (including blood) subtracting the content of the digestive tract, gallbladder and bladder. The samples from each animal were autoclaved, freeze-dried and then their chemical composition and energy content were determined. Energy in wool was calculated from its chemical composition by

TABLE 2

Chemical composition ( $\mathrm{g} / \mathrm{kg}$ dry matter) and energetic value $(\mathrm{MJ} / \mathrm{kg}$ dry matter) of diets

\begin{tabular}{lrrrrr}
\hline & \multicolumn{5}{c}{ Dehydrated lucerne, \% } \\
\cline { 2 - 6 } \multicolumn{1}{c}{ Item } & \multicolumn{1}{c}{5} & \multicolumn{1}{c}{5} & 10 & 15 & 20 \\
\hline Dry mattcr' & 881 & 887 & 879 & 889 & 892 \\
Crude protein & 162 & 159 & 159 & 159 & 160 \\
Ether extract & 38 & 42 & 39 & 39 & 38 \\
Acid detergent fibre & 120 & 108 & 115 & 121 & 127 \\
Ncutral detergent fibrc & 206 & 215 & 221 & 231 & 237 \\
Crude ash & 60 & 61 & 62 & 62 & 63 \\
Metabolizable energy (ME) & 12.9 & 12.9 & 12.9 & 12.8 & 12.7 \\
\hline
\end{tabular}

air dry matter basis 
multiplying the quantity of protein and fat by energy value coefficients (Urbaniak and Potkański, 1987) which equal $5.609 \mathrm{kcal} / \mathrm{g}$ and $9.741 \mathrm{kcal} / \mathrm{g}$, respectively. Energy and protein retention in lamb bodies (including wool) were calculated from the difference between the concentration of these components in the animal body at the beginning and end of the experiment.

The basic chemical composition of feeds, wool and lyophilizates of slaughter products was determined using standard methods. ADF and NDF were determined by the method of Gocring and Van Soest (1970). An automatic calorimeter was used to determine the encrgy content in lyophilizates.

Results were analyzed statistically by analysis of variance (Steel and Torric, 1960) with Duncan's multiple range test used to compare treatment means with significant $\mathrm{F}$ values.

\section{RESULTS}

No health problems were observed in the animals throughout the entire period of the experiment. With the increase of the dietary DL concentration from 0 to $10 \%$, a significant $(\mathrm{P} \leqslant 0.05)$ increase of mean daily live weight gains from 173 in the control group to $191 \mathrm{~g} / \mathrm{d}$ in the group fed $10 \%$ DL was observed (Table 3). Further increase of the DL share in diets to 15 and $20 \%$ slightly reduced the live weight gains to 180 and $178 \mathrm{~g} / \mathrm{d}$, respectively. Clean wool production did not differ significantly among groups, but the highest value of this parameter (4.11 $\mathrm{g} / \mathrm{d}$ ) was found in lambs fed diets containing $10 \% \mathrm{DL}$. Animals from this group used significantly $(\mathrm{P} \leqslant 0.05)$ less crude protein and metabolizable energy per unit of live weight gain.

The level of dietary DL did not have a significant influence on the chemical composition and energetic value of EBW (Table 4). Protein content in $1 \mathrm{~kg} \mathrm{EBW}$ ranged from 181 to $184 \mathrm{~g}$, fat - from 144 to $155 \mathrm{~g}$, while energy value from 12.40 to $12.63 \mathrm{MJ}$. The highest value of the coefficient of utilization energy available for growth was observed in lambs fed the ration containing $10 \%$ DL $(0.33)$, and the lowest in animals from the control group (0.27) (Table 5). Differences between groups were statistically significant $(P \leqslant 0.05)$.

The dietary $D L$ content had a significant $(P \leqslant 0.05)$ effect on protein deposition in the lambs' body (Table 6). The highest quantities of protein were retained by lambs from the group fed $10 \% \mathrm{DL}$ in diet $-29.52 \mathrm{~g} / \mathrm{d}$ in EBW gain, $3.90 \mathrm{~g} / \mathrm{d}$ in wool gain and $33.42 \mathrm{~g} / \mathrm{d}$ of total gain, the lowest by animals from the control group $-22.43 \mathrm{~g} / \mathrm{d}, 3.52 \mathrm{~g} / \mathrm{d}$ and $27.95 \mathrm{~g} / \mathrm{d}$, respectively. Further increase of DL concentration in diets to 15 and $20 \%$ slightly reduced these parameters. Moreover, lambs from the group fed the $10 \%$ DL diet also retained significantly $(\mathrm{P} \leqslant 0.05)$ more protein $(22.58 \%)$ than animals from the control group $(18.51 \%)$. 


\section{DISCUSSION}

The effect of different levels of dietary DL for fattened lambs on production results and protein and energy deposition was determined. The highest lamb live weight gains, feed utilization as well as wool production were observed when the dietary DL concentration was $10 \%$, and then the value of these parameters decreased as the share of DL rose to 15 or $20 \%$. Elucidation of these results can be found in the findings of Urbaniak's and Przybecki's studies (1994) in which they used these same diets with the aim to determine the effect of DL on nitrogen - energetic changes in the rumen and amino acid (AA) flow to the small intestine. The DL used in both experiments was a typical commercial product which contained $19 \%$ crude protein; $61.2 \%$ of this crude protein escaped rumen degradation. The practical significance of these findings is that the diets used in this study, containing from 0 to $20 \% \mathrm{DL}$, were characterized by increasing amounts of rumen non degraded AA. This was the result of, on the one hand, supplementation of the diets with increasing quantities of DL protein of relatively low rumen degradability and, on the other, the decrease in the quantities of cereal feeds (grains + bran) which undergo degradation in this forestomach much easier (Madsen and Hvelplund, 1985). Price et al. (1988) believe that the introduction of $\mathrm{DL}$ into diets results in the decrease of branched-chain fatty acid concentrations in the rumen. This leads to the reduction in the level of AA degradability in the rumen but also can act as a factor limiting the extent of microbial protein synthesis. Under most dietary conditions, the microbial protein synthetized in the rumen accounts for $60-85 \%$ of total AA

TABLF: 3

Live weight gains. wool production and feed utilization by lambs

\begin{tabular}{|c|c|c|c|c|c|c|}
\hline \multirow{2}{*}{ Item } & \multicolumn{5}{|c|}{ Dehydrated lucerne, $\%$} & \multirow{2}{*}{$\mathrm{SE}^{a}$} \\
\hline & 0 & 5 & 10 & 15 & 20 & \\
\hline Initial weight, $\mathrm{kg}$ & 17.5 & 17.7 & 17.6 & 17.7 & 17.5 & 0.9 \\
\hline Final wcight, kg & 35.6 & 35.8 & 35.8 & 35.7 & 35.7 & 1.9 \\
\hline Duration, days & $105^{c}$ & $99^{\circ}$ & $95^{d}$ & $100^{\circ}$ & $102^{c}$ & 60 \\
\hline $\begin{array}{l}\text { Live weight gain, } \mathrm{g} / \mathrm{d} \\
\text { Feed utilization: }\end{array}$ & $173^{\mathrm{c}}$ & $182^{d}$ & $191^{\mathrm{e}}$ & $180^{\mathrm{d} . \mathrm{c}}$ & $178^{\circ}$ & 12 \\
\hline $\begin{array}{l}\text { crude protcin, g/kg gain } \\
\text { metabolizable energy, }\end{array}$ & $876^{\mathrm{c}}$ & $819^{\text {ed }}$ & $780^{\mathrm{d}}$ & $837^{d}$ & $853^{t}$ & 64 \\
\hline $\mathrm{MJ} / \mathrm{kg}$ gain & $69.9^{\mathrm{b}}$ & $66.4^{\mathrm{b}}$ & $60.9^{\circ}$ & $67.6^{b}$ & $67.8^{\mathrm{b}}$ & 5.0 \\
\hline Wool production ${ }^{b}, \mathrm{~g} / \mathrm{d}$ & 3.88 & 4.00 & 4.11 & 3.92 & 3.95 & 0.27 \\
\hline
\end{tabular}


entering the small intestine (Storm et al., 1983) and can influence significantly the degree of covering AA requirements in ruminants. If the theory of Price et al. (1988) is true, then it can be assumed that under the conditions of our experiments, the main cause of the reduction of live weight gains, feed utilization as well as wool production in lambs fed 15 and $20 \%$ DL in diets could be attributed to lower microbial synthesis in the rumen. This could probably result from the too low supply of both branched-chain fatty acid and ammonia- $\mathrm{N}$ in the rumen. Similar beneficial effects of DL on performance in growing ruminants were also observed by other authors. Stroud et al. (1985) found that experimental steers increased their live weight gains by $18.7 \%$, feed intake by $6.4 \%$ and its utilization by about $10 \%$, when their diet was supplemented with $7.9 \%$ DL. Also Rock et al. (1983) and Kirkpatrick et al. (1984) observed improved ruminant performance when their diets included DL.

The present investigations did not reveal a significant effect of different DL levels in diets on the chemical composition of EBW. This fact may confirm the findings of some researchers who indicate that the chemical composition of EBW of lambs slaughtered at the same body weight is relatively stable and only slightly dependent on experimental factors (ARC, 1980; Urbaniak and Potkański, 1987; Fix et al., 1988). The content of dry matter, protein, fat, ash and energy deposited in EBW of lambs in the present study was similar to that found in other investigations carried out on lambs of the Merino type (Fix et al., 1988; Pająk et al., 1992; Urbaniak and Potkański, 1987).

Assessment of utilization of diet metabolizable energy (ME) on lamb growth using the comparative slaughter technique requires determination of the amount of energy intake, energy content in animals" body at the beginning and end of the expcriment as well as maintenance requirements. With the exception of the latter, all the remaining factors were assessed in this study. It was assumed after Thericz et al. (1982), Ørskov and McDonald (1970) and Urbaniak and Potkański (1987)

TABLE 4

Chemical composition (\%) and energetic value of $1 \mathrm{~kg}$ cmpty body weight of lambs

\begin{tabular}{|c|c|c|c|c|c|c|}
\hline \multirow{2}{*}{ Item } & \multicolumn{5}{|c|}{ Dehydrated lucerne, \% } & \multirow{2}{*}{$S E^{a}$} \\
\hline & 0 & 5 & 10 & 15 & 20 & \\
\hline Dry matter & 38.2 & 38.5 & 37.8 & 37.7 & 37.7 & 2.1 \\
\hline Crude protein & 18.2 & 18.1 & 18.4 & 18.2 & 18.3 & 0.9 \\
\hline Ether cxtract & 15.2 & 15.5 & 14.4 & 14.4 & 14.7 & 0.8 \\
\hline Crude ash & 4.8 & 4.9 & 5.0 & 5.1 & 4.7 & 0.2 \\
\hline Gross energy, $\mathrm{MJ} / \mathrm{kg}$ & 12.6 & 12.6 & 12.4 & 12.5 & 12.6 & 0.71 \\
\hline
\end{tabular}

a standard error of the mean 
TABI.F: 5

Metabolizable energy (MF) utilization by lambs

\begin{tabular}{|c|c|c|c|c|c|c|}
\hline \multirow{2}{*}{ Item } & \multicolumn{5}{|c|}{ Dehydrated lucerne, $\%$} & \multirow{2}{*}{ SF } \\
\hline & 0 & 5 & 10 & 15 & 20 & \\
\hline $\begin{array}{l}\text { Total ME intake } \\
\text { (MJ/lamb) }\end{array}$ & 1265 & 1203 & 1108 & 1217 & 1235 & 99 \\
\hline $\begin{array}{l}\text { Maintenance requirement } \mathrm{t}^{\mathrm{b}} \\
(\mathrm{MJ})\end{array}$ & 513 & 483 & 464 & 488 & 498 & 31 \\
\hline $\begin{array}{l}\text { ME available for growth } \\
\text { (MIJ) }\end{array}$ & 753 & 719 & 644 & 729 & 737 & 52 \\
\hline Energy deposition (MJ) & 204 & 212 & 211 & 219 & 223 & 12 \\
\hline MF utilization $\left(k_{f}\right)$ & $0.27^{\prime \prime}$ & $0.29^{4}$ & $0.33^{\circ}$ & $0.30^{4}$ & $0.30^{d .}=$ & 0.02 \\
\hline
\end{tabular}

" standard error of the mean

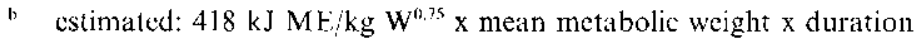

- wool included

d, $c$ means in the same row bearing different superscripts differ $P \leqslant 0.05$

TABLE 6

Protein deposition in lambs' body

\begin{tabular}{|c|c|c|c|c|c|c|}
\hline \multirow{2}{*}{ Item } & \multicolumn{5}{|c|}{ Dehydrated lucerne. \% } & \multirow{2}{*}{ SE: } \\
\hline & 0 & 5 & 10 & 15 & 20 & \\
\hline Protein inlake, g/d & $15 \mathrm{l}$ & 150 & 148 & 151 & 152 & 10 \\
\hline \multicolumn{7}{|l|}{ Protein deposition: } \\
\hline in EBW gain, g/d & $24.4^{\mathrm{b}}$ & $26.4^{\mathrm{h}}$ & $29.5^{\mathrm{c}}$ & $27.5^{c}$ & $27.4^{r}$ & 1.17 \\
\hline in wool gain, $\mathrm{g} / \mathrm{d}$ & $3.5^{b}$ & $3.7^{7}$ & $3.9^{\prime \prime}$ & $3.7^{1 \times}$ & $3.7^{b}$ & 0.16 \\
\hline total. $\mathrm{g} / \mathrm{d}$ in $1 \%$ of protein & $27.9^{\mathrm{b}}$ & $30.2^{\mathrm{c}}$ & $33.4^{4}$ & $31.1^{4}$ & $31.1^{\text {t }}$ & 2.02 \\
\hline intake & $18.5^{5}$ & $20.1^{3}$ & $22.6^{\mathrm{c}}$ & $20.6^{\mathrm{c}}$ & $20.5^{\mathrm{b}}$ & 1.11 \\
\hline
\end{tabular}

standard error of the mean

b.: al means in the same row bearing different superscripts differ $P \leqslant 0.05$

that maintenance requirements amounted to $418 \mathrm{~kJ} / \mathrm{kg} \mathrm{W}^{0.75}$. In the present study the highest value of the $\mathrm{k}_{\mathrm{f}}$ coefficient was recorded in lambs fed dicts containing $10 \%$ DL. Blaxter and Boyne (1978) maintain that the utilization of dietary energy depends not only on the q value (ME/GE), but also on the content of total protein and crude fibre. In this experiment all diets had similar values of these parameters and differed only in the concentration of DL. Therefore, under these conditions, the fact that the lambs from the group fed diets containing $10 \% \mathrm{DL}$ obtained the maximum value of the $k_{\mathrm{p}}$ coefficient indicates explicitly that the level of supplementation was optimal. The values of $k_{f}$ obtained in the present study correspond with the results of other authors (Thomson and Cammel, 1979; Theriez et al., 1982; Urbaniak and Polkański, 1987). The total quantity of the 
protein deposited in the lambs' body (EBW gain + wool gain) increased from $27.95 \mathrm{~g} / \mathrm{d}$ to $33.42 \mathrm{~g} / \mathrm{d}$ when the concentration of dietary DL increased from 0 to $10 \%$, and decreased when the dietary DL concentration increased further, i.e. to 15 and $20 \%$. The observed tendency was similar as in the case of utilization of $\mathrm{MF}$ for growth and production results. The quantity of protein deposited by lambs corresponded with the $\mathrm{N}$ retention in growing sheep in the experiments of Ørskov and Grubb (1979) and Amos and Evans (1980), 4.6-6.2 and 3.7-6.2 g/d, respectively which was determined by traditional methods (collection of facces and urine), as well as with the results of studies by Urbaniak and Potkański (1987) and Pająk et al. (1992) in which the comparative slaughter technique was employed.

Summarizing, it may be concluded that under the conditions of this study the optimal level of DL in all-concentrate, pelleted diets was $10 \%$. This level of supplementation gave the best production results and the highest deposition of protein and energy in animals' body.

\section{REFERENCES}

Amos II.E., Evans 1.J., 1980. Nitrogen metabolism of growing lambs fed coastal bermudagrass as influenced by formaldehyde treatment and glucose. J. Anim. Sci. 51, 712.721

ARC, 1980. The Nulrient Requirements of Ruminant Livestock. Commonwealth Agric. Bureaux. Iondon

Blaxter K.L., Boyne A.W., 1978. The estimation of nutritive value of feeds as energy sources for ruminants and the deviation of fecding system. J. Agric. Res. 90, 47-68

Christensen D.A., Cochran M.I., 1983. Composition and nutritive value of dehydrated alfalfa for lactating dairy cows. J. Dairy Sci. 66, 2282-2291

Fix H.P., Brutzke M., Peschke I., Jloffmann M., 1988. Untersuchungen zum Stoff- und Energieansatz wachsender Lämmer. 2. Ergebnisse der Ausschlachtungen und Tierkörperaanalysen. Arch. Anim. Nutr. (Berlin) 38, 327-341

Goering H.K., Van Soest P.J., 1970. Forage Fibre Analysis, USDA, ARS. Agric. Handbook. No. 379

Ia J.K., Emerich R.J., Embry I..B.. 1983. In vitro effect of $\mathrm{pH}$ variations on rumen fermentation and in vivo effect of buffers in lambs before and after adaptation to high-concentrate diets. J. Anim. Sci. $56,698-706$

Kirkpatrick B.K.. Christensen D.A., Cochran M.I., 1984. Dehydrated lucerne as a concentrate substitute in rations for lactating dairy cows. J. Anim. Sci. 67, 2315-2320

Linda G.J., Wohlt F.J., 1985. Effect of supplementing equi-yalent cation amounts from $\mathrm{NaCl}, \mathrm{MgO}$, $\mathrm{NaHCO}_{3}$ and $\mathrm{CaCO}_{3}$ on nutrient utilization and acid-base status of growing Dorset lambs fed high concentrate diets. J. Anim. Sci. 60, 307-315

Loerch S.C., Berger L.L., Plegge S.D., Fahcy G.C.. Jr., 1983. Digestibility and rumen escape of soybean meal, blood meal, meat and bone meal and dehydrated alfalfa nitrogen. J. Anim. Sci. $57,1037-1047$

Madsen J., Hvelplund T., 1986. Protein degradation in the rumen. A comparison between in vivo, nylon bag and buffer measurements. Acta Agric. Scand. 25 (Suppl.), 103-124 
MAFF, 1975. Energy Allowances and Feeding System for Ruminants. London, Techn. Bull. 33

Ørskov E.R., Grubb D.A., 1979. Growth of storc lambs on cereal based diets with protein and urea. Anim. Prod. 29, 371-377

Orskov E.R., MCDonald I., 1970. The utilization of dietary energy for maintenance and for fat and protcin deposition in young growing sheep. Eur. Assoc. Anim. Prod. 13, 121-124

Pająk J., Żebrowska T., Żebrowska H., 1992. Protein content in the diet for fattening lambs. 2. The chemical and amino acid composition of the body and utilization of amino acids apparentiy absorbed in the small intestine. J. Anim. Feed Sci. 1, 27-36

Rock D.W., Klopfenstein T.J., Ward J.K., Britton R.A., McDonald E.R., 1983. Evaluation of slowly degraded proteins: dehydrated alfalfa and corn gluten meal. J. Anim. Sci. 56, 476-482

Steel R.G.D., Torrie J.H.. 1960. Principles and Procedures of Statistics. McGrow-Hill Book Co., New York

Storm E., Ørskov E.R., Smart R., 1983. 'The nutritive value of rumen microorganisms in ruminants. 2. The apparent digestibility and net utilization of microbial $\mathbf{N}$ for growing lambs. Brit. J. Nutr. $50,471-478$

Stroud T.E., Williams J.E., Ledoux D.R., Peterson J.A., 1985. The influence of sodium bicarbonate and dehydrated alfalfa as buffers on steer performance and ruminal characteristics. J. Anim. Sci. $60,551-559$

Theriez M., Villette Y., Castrillo C., 1982. Influence of metabolizable energy content of the diet and of feeding level on lamb performance. II. Utilization of metabolizable energy for growth and fattening. Livest. Prod. Sci. 9, 487-500

Thomson D.J., Cammel S.B., 1979. The utilization of chopped and pelleted lucerne (Medicago sariva) by growing lambs. Brit. J. Nutr. 41, 297-310

Urbaniak M., Potkański A., 1987. Tissue protein and energy deposition in lamb body fed isocaloric complete pelleted diets with different levels of nitrogen. Proceedings of the 5th International Symposium on Protein Metabolism and Nutrition, Rostock, Germany

Urbaniak M., Przybecki T., 1994. Effect of dehydrated lucerne on ruminal characteristics and amino acids flow through the lambs duodendum. Anim. Feed Sci. Technol. (in press)

\section{STRESZCZENIE}

\section{Wpływ suszu z lucerny na wyniki produkcyjne jagniąt oraz odłożenie białka i energii w ciele}

Czterdzieści tryczków rasy merynos polski, ważących okolo $17 \mathrm{~kg}$, podzielono na 5 grup i żywiono pięcioma izobiałkowymi i izoenergetycznymi dawkami zawierającymi $0,5,10,15$ lub 20\% suszu z lucerny (DL).

Zwierzęta tuczono do końcowej masy ciała około $36 \mathrm{~kg}$. Wraz ze wzrostem udziału DL w dawkach od 0 do $10 \%$ istotnie $(\mathrm{P} \leqslant 0.05)$ wzrosty średnie dzienne przyrosty masy ciała, odpowiednio od 173 do $191 \mathrm{~g} / \mathrm{d}$. Przy zwięks/eniu zawartości DL w dawkach do 15 i $20 \%$ przyrosty dzienne obnizyły się do 180 i 178 g. Jagnięta żywione dawką zawierającą $10 \%$ DL zużywały mnicj białka i energii na jednostkę proyrostu niz z pozostałych grup. Udział DL w dawkach nic miał istolnego wpływu na sklad chemiczny i wartość encrgetyczną $1 \mathrm{~kg}$ masy ciała netto (MCN). Najwyższą wartość współczynnika wykorzystania energii metabolicznej na wzrost $\left(k_{f}\right)$ stwierdzono u jagniąt żywionych dawką zawierająca 10\% DL (0.33), najniższą u jagniąt z grupy kontrolncj $(0.27)$. Jagniçta otrzymujące w dawce $10 \%$ DL odkładaly istotnic więcej $(P \leqslant 0.05)$ białka w MC.N $(29.5 \mathrm{~g} / \mathrm{d})$, w przyroście wełny $(3.9 \mathrm{~g} / \mathrm{d}) \mathrm{i}$ w całkowitym przyrościc $(33.4 \mathrm{~g} / \mathrm{d})$ niż zwierzęta grupy kontrolnej. 